DOI: $10.22363 / 2312-9182-2018-22-3-499-520$

\title{
Anna Wierzbicka, Words and the World
}

\author{
Anna Gladkova ${ }^{1,2}$ and Tatiana Larina ${ }^{3}$ \\ ${ }^{1}$ Monash University \\ 20 Chancellors Walk, Clayton Campus, Monash University \\ ${ }^{2}$ Australian National University \\ Melbourne, VIC 3800, Australia \\ ${ }^{3}$ Peoples' Friendship University of Russia (RUDN University) \\ 6, Miklukho-Maklaya, 117198, Moscow, Russia
}

\begin{abstract}
This introduction to the Special Issue summarises Anna Wierzbicka's contribution to the linguistic study of meaning. It presents the foundations of the approach known as the Natural Semantic Metalanguage (NSM) developed by Wierzbicka. The current state of the approach is discussed in the article with the ideas of 65 semantic primitives, universal grammar and the principle of reductive paraphrase in semantic explications. It traces the origin of Wierzbicka's ideas to Leibniz. The framework has been tested on about thirty languages of diverse origin. The applications of the approach are broad and encompass lexical areas of emotions, social categories, speech act verbs, mental states, artefacts and animals, verbs of motion, kinship terms (among others), as well as grammatical constructions.
\end{abstract}

Keywords: Anna Wierzbicka, semantics, Natural Semantic Metalanguage (NSM), semantic primitives, reductive paraphrase

\section{Анна Вежбицкая, слова и смыслы}

\author{
А.Н. Гладкова ${ }^{1,2}$, Т.В. Ларина ${ }^{2}$ \\ ${ }^{1}$ Monash University \\ 20 Chancellors Walk, Clayton Campus, Monash University \\ ${ }^{2}$ Australian National University \\ Melbourne, VIC 3800, Australia \\ ${ }^{3}$ Peoples' Friendship University of Russia (RUDN University) \\ 6, Miklukho-Maklaya, 117198, Moscow, Russia
}

\begin{abstract}
Аннотация
В вводной статье к специальному выпуску, посвященному семантическим исследованиям, обобщается вклад Анны Вежбицкой в языковые исследования смысла. В ней представлены основы разработанного ею подхода Естественного Семантического Метаязыка (ЕСM) и обсуждаются последние разработки данного подхода, которые включают 65 семантических примитивов, универсальную грамматику и принцип упрощенных перифраз. Прослеживается связь между идеями А. Вежбицкой и Г.В. Лейбница. Универсальность подхода тестировалась на более тридцати языках различного происхождения. Подход имеет широкое применение и успешно используется в анализе терминов эмоций, социальных категорий, глаголов речевого действия, ментальных состояний, артефактов и животных, глаголов движения, терминов родства, а также грамматических конструкций.
\end{abstract}

Ключевые слова: Анна Вежбиикая, семантика, Естественный Семантический Метаязык (ЕCM), семантические примитивы, упрощенные перифразы 


\section{INTRODUCTION}

The current and the next issue of the Russian Journal of Linguistics are dedicated to Anna Wierzbicka. Anna Wierzbicka is an internationally renowned linguist who systematically integrated language, culture and cognition in her studies and demonstrated the logic of culture-specific modes of linguistic interaction. In 2018 Anna Wierzbicka celebrates her anniversary and the Russian Journal of Linguistics highjacks two issues to celebrate her scholarship and the warmth of her personality. Those of us who are fortunate to know her personally are moved by her kindness and moral support. She has been an inspiration to a countless number of colleagues, young scholars, and students in Russia and beyond. Over the years her scholarship, intellectual rigor, and academic integrity have been exemplary. The Editorial Board of the journal, the authors and the readers wish that her intellectual journey will continue for many more years to come.

Professor Anna Wierzbicka is a Professor Emeritus in Linguistics at the Australian National University in Canberra, Australia. She is a Fellow of the Australian Academy of the Humanities, the Australian Academy of Social Sciences, the Russian Academy of Sciences, and the Polish Academy of Arts and Sciences. She is the recipient of two Honorary Doctoral Awards from the Marie Curie-Sklodowska University, Poland (2004) and from the Warsaw University, Poland (2006). She is also the recipient of the Dobrushin Prize 2010 (established in Russia in honour of the Russian mathematician Roland Lvovich Dobrushin) and the Polish Science Foundation Prize 2010 for the humanities and social sciences. Anna Wierzbicka is well known for her contributions in the field of semantics and the development of the Natural Semantic Metalanguage (NSM). Her work spans a number of disciplines, including anthropology, psychology, cognitive science, philosophy and religious studies in addition to linguistics. She has published over twenty books and edited or co-edited several others.

Anna Wierzbicka is a widely acclaimed scholar in the Russian linguistic circles. Five books of hers (Wierzbicka 1996, 1999b, 2001a, b, 2011) along with numerous articles have been published in Russia. In this regard, Elena Paducheva rightly notes (2009[1996]: 629):

Undoubtedly, the influence of Wierzbicka's scholarship on linguistic studies in Russia (in general linguistics and Russian linguistics in the first place) is notably greater than in any other country. This could be due to the original Slavic commonality which successfully overcomes territorial and language barriers, but, most likely, this is due to the consonance of linguistic paradigms [...]. In Russian linguistics, one is unlikely to find another author who is cited as widely and passionately as Wierzbicka [...]. (Translation is ours - $A G, T L$ )

The first volume relates to Anna Wierzbicka's contribution to the development of the theory of meaning and her methodology of linguistic analysis known as the Natural Semantic Metalanguage. Consequently, the introductory article to the first volume summarises her contribution to the study of meaning. The main focus of the second volume will be Anna Wierzbicka's research dealing with the relationship between meaning and culture as well as other applications of her approach. 


\section{NATURAL SEMANTIC METALANGUAGE: A BRIEF OVERVIEW}

The most distinctive feature of Anna Wierzbicka's linguistic research is attention to meaning. At the time of linguistics being dominated by formal and structuralist approaches centered on syntax, Wierzbicka suggested a daring shift in the paradigm by stating that meaning is what language is primarily about and that the study of language should first and primarily be conducted through the prism of meaning. Wierzbicka (1996: 3) famously declared:

To study language without reference to meaning is like studying road signs from the point of view of their physical properties (how much they weigh, what kind of paint are they painted with, and so on), or like studying the structure of the eye without any reference to seeing.

Being committed to the principle of the centrality of meaning to linguistic analysis, Wierzbicka set a research agenda of developing a way of studying linguistic meaning that could be versatile enough to give access to a variety of linguistic phenomena and be applicable across languages. In her 1972 book "Semantic Primitives" she launched a theory which is now known under the acronym "NSM" (Natural Semantic Metalanguage) and is being internationally recognized as one of the world's leading theories of language and meaning.

\subsection{Semantic primitives}

Inspired by Leibniz's idea that all languages have a finite number of concepts by means of which other concepts can be explained Wierzbicka set an agenda of identifying these concepts by the process of a detailed linguistic analysis of different semantic domains (cf. Wierzbicka 1972). Leibniz acknowledged that some words are more basic and simple in meaning than others: "Amongst the words, some are frequently used and serve as auxiliary to the others" (Leibniz 1987[1678]: 162). He called these words "the alphabet of human thoughts" (cf. Wierzbicka 1972: 6).

Goddard and Wierzbicka (2014a: 11) write:

One has to attempt a very large number of definitions to be able to find out which words can, and which cannot, be defined, and consequently, which words (or word-meanings) can be regarded as elementary building blocks out of which all complex concepts (and word-meanings) can be built.

This agenda had been pursued by Wierzbicka throughout her career passionately and diligently.

Wierzbicka's (1972) initial list of universal human concepts, or primes, included 14 words. Over the years, this list considerably expanded and developed into a versatile metalanguage of linguistic analysis. This development was due above all to collaboration with Cliff Goddard (currently Professor of Linguistics at Griffith University in Australia), and also to collaboration with other colleagues who applied and tested the metalanguage in a considerable number of unrelated languages ${ }^{1}$. The metalanguage was given the name

${ }^{1}$ It is also important to acknowledge the synergy between the Natural Semantic Metalanguage approach, the Moscow School of Semantics (Apresjan 1992, 2005) and the Meaning-Text Theory (Mel'čuk 1989, 2012, 2013, 2015). 
the "Natural Semantic Metalanguage" because it is based on the concepts expressed as words of natural language (any natural language) and because it was primarily developed as a tool for semantic analysis. The theory has advanced significantly over more than 40 years. It continues to develop and some aspects continue to be clarified and refined. The current state of the theory is reflected in Wierzbicka (1996), Goddard and Wierzbicka (eds. 2002, 2014a), as well as Goddard $(2011,2018)^{2}$.

In identifying universal human concepts the NSM theory accepts Leibniz's hypothesis that they should be shared by people regardless of the language they speak. The NSM theory suggests that there are 65 meanings or human concepts of this kind (see Table 1). These meanings are called semantic primitives or primes and they have been identified by a process of trial and error.

Exponents of semantic primes in English and Russian

(after Gladkova 2010, Goddard and Wierzbicka 2014a)

\begin{tabular}{|c|c|}
\hline JA, TY, KTO-TO, ČTO-TO VEŠČ', LJUDI, TELO & \multirow[t]{2}{*}{ substantives } \\
\hline I, YOU, SOMEONE, SOMETHING THING, PEOPLE, BODY & \\
\hline ROD VID, ČAST' & \multirow[t]{2}{*}{ relational substantives } \\
\hline KINDS, PARTS & \\
\hline ĖTOT, TOT ŽE, DRUGOJ & \multirow[t]{2}{*}{ determiners } \\
\hline THIS, THE SAME, OTHER ELSE & \\
\hline ODIN, DVA, NEKOTORYE, VSE, MNOGO, MALO & \multirow[t]{2}{*}{ quantifiers } \\
\hline ONE, TWO, SOME, ALL, MUCH MANY, LITTLE FEW & \\
\hline XOROŠIJ XOROŠO, PLOXOJ PLOXO & \multirow[t]{2}{*}{ evaluators } \\
\hline GOOD, BAD & \\
\hline BOL'ŠOJ, MALEN'KIJ & \multirow[t]{2}{*}{ descriptors } \\
\hline BIG, SMALL & \\
\hline ZNAT', DUMAT', XOTET', NE XOTET', ČUVSTVOVAT', VIDET', SLYŠAT' & \multirow[t]{2}{*}{ mental predicates } \\
\hline KNOW, THINK, WANT, DON'T WANT, FEEL, SEE, HEAR & \\
\hline GOVORIT' SKAZAT', SLOVA, PRAVDA & \multirow[t]{2}{*}{ speech } \\
\hline SAY, WORDS, TRUE & \\
\hline DELAT', PROISXODIT' SLUČAT'SJA, DVIGAT'SJA & \multirow[t]{2}{*}{ actions, events, movement } \\
\hline DO, HAPPEN, MOVE & \\
\hline 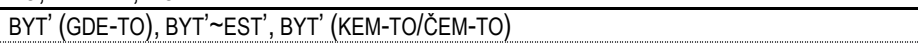 & \multirow{2}{*}{$\begin{array}{l}\text { location, existence, } \\
\text { specification }\end{array}$} \\
\hline BE (SOMEWHERE), THERE IS, BE (SOMEONE/SOMETHING) & \\
\hline $\mathrm{MOJ} / \mathrm{MOJA} / \mathrm{MOE}$ & \multirow[t]{2}{*}{ possession } \\
\hline (IS) MINE & \\
\hline ŽIT', UMERET' & \multirow[t]{2}{*}{ life and death } \\
\hline LIVE, DIE & \\
\hline $\begin{array}{l}\text { KOGDA VREMJA, SEJČAS, DO, POSLE, DOLGO, KOROTKOE VREMJA, NEKOTOROE VREMJA, } \\
\text { MOMENT }\end{array}$ & \multirow[t]{2}{*}{ time } \\
\hline $\begin{array}{l}\text { WHEN TIME, NOW, BEFORE, AFTER, A LONG TIME, A SHORT TIME, FOR SOME TIME, MO- } \\
\text { MENT }\end{array}$ & \\
\hline GDE MESTO, ZDES', NAD, POD, DALEKO, BLIZKO, STORONA, VNUTRI, KASAT'SJA & \multirow[t]{2}{*}{ place } \\
\hline WHERE PLACE, HERE, ABOVE, BELOW, FAR, NEAR, SIDE, INSIDE, TOUCH & \\
\hline NE, MOŽET BYT', MOČ', POTOMU ČTO, ESLI & \multirow[t]{2}{*}{ logical concepts } \\
\hline NOT, MAYBE, CAN, BECAUSE, IF & \\
\hline OČEN', BOL'ŠE EŠČE & \multirow[t]{2}{*}{ intensifier, augmentor } \\
\hline VERY, MORE & \\
\hline KAK TAK & \multirow[t]{2}{*}{ similarity } \\
\hline LIKE AS & \\
\hline
\end{tabular}

Notes: • Exponents of primes can be polysemous, i.e. they can have other, additional meanings. $\bullet$ Exponents of primes may be words, bound morphemes, or phrasemes. • They can be formally complex. • They can have language-specific combinatorial variants (allolexes, indicated with $\sim$ ). Each prime has well-specified syntactic (combinatorial) properties.

${ }^{2}$ The NSM Homepage is a good source of updated information on the approach. It has downloadable materials and a full bibliography of NSM-based publications. 
They constitute the core of human lexicon and can be used to explicate more complex meanings. Apart from words, these meanings can be expressed by bound morphemes or phrasemes. These meanings equal lexical units (cf. Apresjan 1992, Mel'čuk 1988). This means that if a word is polysemous, the meaning of a prime equals only one meaning of this word. To distinguish the meaning of a prime from the other meanings of a given word (in printed text), the primes are, by convention, represented by small capital letters (e.g., THINK, GOOD, PEOPLE).

Wierzbicka's inspirational ideas about the universal metalanguage have been tested by different scholars in a number of typologically divergent languages: Malay, Mandarin Chinese, Polish, Spanish, Lao, Mangaaba-Mbula (in Goddard and Wierzbicka eds. 2002), Hawaii Creole English (Stanwood 1997), Korean, Amharic, Cree (in Goddard ed. 2008), French, Spanish, Italian, Portuguese (in Peters ed. 2006), Russian (Gladkova 2010), Arabic, Hebrew (Habib 2011), Finnish (Vanhatallo et al. 2014). Partial studies of NSM primes and syntax have been conducted on the basis of another two dozen languages (e.g., Goddard and Wierzbicka eds. 1994).

\subsection{Universal grammar}

The primes constitute a metalanguage because they have an ability to combine with each other in different ways. As Wierzbicka (1996: 19) notes:

Despite its obvious limitations, Leibniz's old metaphor of an "alphabet of human thoughts" is still quite useful here: conceptual primitives are components which have to be combined in certain ways to be able to express meaning.

The primes are united by a governing syntax. That is, each prime is identified as being able to combine with certain other primes. They form a mini-language which lies at the core of every language. The syntactic properties of primes are revealed in their valency options. For example, the prime SAY allows a universal valency option of "addressee" and "locutionary topic" — "someone (X) said something to someone else (Y)' and 'someone (X) said something about something (Z)'. Similarly, the exponent of SAY in Russian - GOVORIT' SSAZAT' - has the same syntactic properties as its English exponent. In Russian these sentences with GOVORIT'SKAZAT' are 'kto-to $(X)$ skazal čto-to komu-to drugomu (Y)' and 'kto-to (X) skazal čto-to o čem-to (Z)' respectively.

The 'syntactic properties' of the primes are identified in the list of canonical contexts or canonical sentences (Goddard and Wierzbicka eds. 1994, 2002). Canonical contexts are combinations of primes which reflect their syntactic properties and which can be used in semantic explications. The prime SAY has the following canonical sentences (Goddard and Wierzbicka 2002: 60):

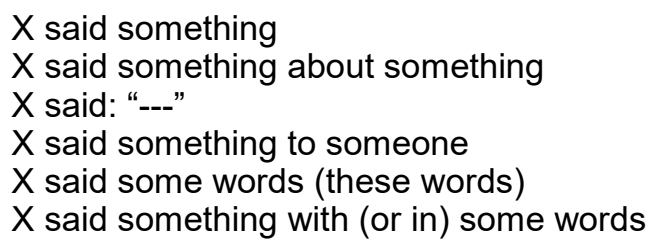

Most recent overview of canonical sentences is presented in Goddard and Wierzbicka (2014b). 


\subsection{Reductive paraphrase principle and semantic explications}

The primes in their canonical combinations are used to explicate meaning in the form of reductive paraphrase. Wierzbicka (1996) identifies the importance of paraphrase in semantic studies as follows:

Semantics can have an explanatory value only if it manages to "define" (or explicate) complex and obscure meanings in terms of simple and self-explanatory ones. If a human being can understand any utterances at all (someone else's or their own) it is only because these utterances are built, so to speak, out of simple elements which can be understood by themselves (Wierzbicka 1996: 11).

Semantic explications written in NSM present formulae which can be substituted for the meanings explained. A formula of this kind is written in the form of a mini text with each component presented on a new line. Each component is related to the previous component, more precisely, it has an anaphoric relationship with the previous components.

The following is an example of a semantic explication of the English word happy worded in NSM (Goddard and Wierzbicka 2014a: 103):

\section{He was happy}

a. this someone thought like this for some time at that time:

b. $\quad$ "many good things are happening to me now as I want

c. I can do many things now as I want

d. this is good"

e. because of this, this someone felt something good at that time

f. like people feel at many times when they think like this for some time

The universality of the "primitive" concepts and their syntactic properties used in the NSM allows for the explications to be translatable into any language without any loss or addition in meaning. The Russian version of this explication would be:

\section{He was happy}

a. ètot kto-to dumal tak nekotoroe vremja $v$ to vremja:

b. "mnogo xorošix veščej proisxodit so moj sejčas kak ja xoču

c. ja mogu delat' mnogo veščej kak ja xoču

d. èto xorošo

e. poètomu, ètot kto-to čuvstvoval čto-to xorošee $v$ èto vremja

f. kak ljudi čuvstvujut často, kogda oni dumajut tak nekotoroe vremja

Similarly, this explication can be represented in any version of NSM without any change of meaning due to universality of the metalanguage.

The NSM has developed into a versatile tool that has been successful in the analysis of a large variety of linguistic phenomena. Wierzbicka and her followers have applied it in the study of emotions (e.g., Wierzbicka 1992, 1999, 2009, 2017), social categories (Wierzbicka 1997), speech act verbs (Wierzbicka 1987), mental states (Wierzbicka 2006), artefacts and animals (Wierzbicka 1985), verbs of motion (Goddard, Wierzbicka 
and Wong 2016), kinship terms (Wierzbicka 2015) (to name just a few). It has also served in explications of meanings of grammatical constructions (e.g., Wierzbicka 1988, 2006, Goddard and Wierzbicka 2016) . $^{3}$

With the pool of knowledge acquired from the analysis of diverse vocabularies and grammars, especially in a cross-linguistic perspective, Wierzbicka developed a way of applying her approach to the study of cultural phenomena embedded in language. This led to the idea of the salience of cultural key words (Wierzbicka 1997) and cultural scripts (Wierzbicka 2002, 2003). We will cover these aspects of Wierzbicka's approach and work in the next issue of the Russian Journal of Linguistics.

\section{THE ARTICLES OF THIS ISSUE}

The current issue comprises articles written by Anna Wierzbicka's colleagues, friends and collaborators who either directly use her approach of linguistic analysis or are considerably influenced by it.

The first article is written by Igor Mel'čuk (Montreal, Canada), the creator of the Meaning-Text linguistic approach (Mel'čuk 2012, 2013, 2015, 2016). In this article he argues that the main contribution of Anna Wierzbicka to linguistics is the idea of semantic decomposition - that is, representing meaning in terms of structurally organized configurations of simpler meanings. He further demonstrates how this idea can be applied using two Meaning-Text mini-models for English and Russian at four levels - semantic, deep-syntactic, surface-syntactic, and deep-morphological. Examples of formal rules relating the representations of two adjacent levels are presented.

In the next article, Cliff Goddard (Brisbane, Australia) - a long-term Anna Wierzbicka's collaborator and a co-developer of the Natural Semantic Metalanguage, follows the seminal work of Wierzbicka $(1985,2013)$, and proposes and discusses a set of semantic analyses of words from three different levels of the English ethnozoological taxonomic hierarchy: creature (unique beginner), bird, fish, snake, and animal (life-form level), dog and kangaroo (generic level). The research is conducted using the analytical framework of the Natural Semantic Metalanguage approach (Wierzbicka 1996, 2014, Goddard and Wierzbicka 2014a). The work implements NSM constituents semantic primes, semantic molecules and semantic templates (Goddard 2012, 2016). Other issues considered include the extent to which cultural components feature in the semantics of ethnozoological categories, and the extent to which semantic knowledge may vary across different speech communities.

Sally Rice and John Newman (Edmonton, Canada) investigate the usage in English of basic verbs of ideation (think, know) and physical activity (strike, hit, go, run) as they take on new epistemic meanings and functions. The choice of words and meanings overlaps with some semantic primes from Wierzbicka's Natural Semantic Metalanguage. The authors find that many verbs and phrasal expressions, ideational or not, seem

${ }^{3}$ A full bibliography of Anna Wierzbicka's work is available on her ANU webpage and the NSM Homepage. 
to be associated with rather narrow collocational patterning, argument structure, and inflectional marking in almost idiom-like and constructional fashion. Moreover, it is argued that expressions associated with $1 \mathrm{SG}$ and $2^{\text {nd }}$ person "cognizers" are, to a large extent, in complementary distribution, giving rise to fairly strong semantic differences in how $I$ and you "ideate". This study demonstrates the extent of inflectional and collocational specificity for verbs of cognition and physical activity and discuss implications that lexico-syntactic idiosyncracy has for cognitive linguistics.

Jock Onn Wong (Singapore) demonstrates how the Natural Semantic Metalanguage can be applied in language teaching. In particular, he uses it to capture the meaning of three logical connectors, therefore, moreover and in fact for English language teaching purposes. He demonstrates that the knowledge and understanding of the meaning of these words is essential for constructing logical texts and building logical connections. The author explains that the advantages of using simple universal concepts for explicating such words for pedagogical purposes are their accessibility and non-ethnocentric nature.

The paper by Ekaterina Rakhilina (Moscow, Russia) and Aimgul Kazkenova (Almaty, Kazakhstan) also relates to the issues of language pedagogy and deals with a well-known problem of the distribution of grammatical markers within a certain category and whether this distribution is motivated semantically or not. It discusses the choice of singular and plural forms of nouns in Russian texts. The paper builds on Anna Wierzbicka's seminal work recognizing that the rules which regulate the usage of number markers in Russian are language-specific (Wierzbicka 1988). The research relies on data from Kazakh-Russian bilinguals. The paper demonstrates that the deviations in nominal number marking in the texts of bilinguals are not arbitrary but semantically motivated. They follow semantic strategies which are characteristic of speakers appealing to both systems at once. The paper argues that the violation of standard usage observed in the learner corpus can specify the rules governing Russian number usage which have been violated.

Anna Zalizniak and Elena Paducheva (Moscow, Russia) address their article to the analysis of discourse markers with the meaning "speaker's opinion about a certain state of affairs". The paper builds on Wierzbicka's research discussing the presence of the speaker in the utterance (e.g., Wierzbicka 1972, 1987, 2003[1991]). The paper presents an analysis of three Russian discourse words pozhaluj, nikak, vsjo-taki based on the National Corpus of Russian data. The study offers the prospect of an integral research of discourse words which combines methods of classical semantic analysis, contextual-semantic method, conceptual analysis and narratology.

Valentina Apresjan (Moscow, Russia) presents a corpus-based study of Russian reduplicated constructions with colour terms. The study establishes that absolute frequencies of non-reduplicated colour terms in Russian reflect both Anna Wierzbicka's "universals of visual semantics" (Wierzbicka 1990, 2005), as well as certain language and culture-specific tendencies. Her findings establish the importance of corpus methods 
in the study of colour terms and reduplication, demonstrate that the use and interpretation of lexical and syntactic items hinges both on semantic and pragmatic factors, and add to the understanding of semantics and pragmatics of Russian colour terms and reduplication construction.

The article by Alexei Shmelev (Moscow, Russia) deals with the Russian words referring to 'freedom' (svoboda, volja, and their derivatives svobodnyj, vol'nyj, vol'nost', etc.) in both synchronic and diachronic aspects. It seeks to elaborate and to refine the analysis given in some earlier publications by Wierzbicka (1997) and Shmelev (Shmelev 2003, 2013). The paper analyzes the spatial dimension in the meaning of the words under consideration, the contrast between svoboda and volja before the Revolution, their semantic development during Soviet times and their current semantic status. In addition, the author considers the use of the words in question in the translations of various texts into Russian (with reference to the parallel corpora of the Russian National Corpus).

The issue concludes with a Review Article by Elizaveta Kotorova (Zielona Góra, Poland). The author reviews three recent articles by Anna Wierzbicka on kinship terminology. It demonstrates how Wierzbicka introduces a novel way of analysing the semantics of kinship terms by using the methodology of Natural Semantic Metalanguage. It is shown that this kind of approach allows the researcher to successfully overcome Eurocentrism in studying kinship terminology in diverse languages by relying on universals of human cognition.

\section{CONCLUDING REMARKS}

The Special Issue dedicated to Wierzbicka in recognition of her contributions to linguistics will be continued in the next issue. It will focus on Anna Wierzbicka's research aimed at the relationship between language and culture and other applications of her approach to studying meaning.

We would like to express sincere gratitude to all authors contributing to this issue. We would also like to congratulate again Anna Wierzbicka on her anniversary and to thank her for her inspiring work, generosity, moral support and kindness.

\section{RU}

\section{1. ВВЕДЕНИЕ}

Этот и следующий выпуск нашего журнала мы посвящаем всемирно известному лингвисту - Анне Вежбицкой, много сделавшей для демонстрации системной связи между языком, культурой и мышлением и выявления логики культуры, воплощенной в языке и коммуникации. В этом году Анна Вежбицкая отмечает свой юбилей, и мы вместе с ее друзьями, коллегами и учениками, почитателями 
ее таланта и прекрасных человеческих качеств решили преподнести ей этот интеллектуальный подарок. Тех из нас, кому повезло встречаться с Анной и узнать ее лично, всегда покоряли ее доброта, открытость, постоянное желание поддержать и помочь. Своими новаторскими идеями, неустанным научным поиском и преданностью науке она вдохновляла и продолжает вдохновлять своих коллег, молодых ученых и студентов в России и за ее пределами.

От имени редколлегии нашего журнала, наших авторов и читателей мы сердечно поздравляем Анну Вежбицкую с замечательным юбилеем и желаем ей доброго здоровья и новых творческих достижений!

Анна Вежбицкая - заслуженный профессор лингвистики Австралийского национального университета, член Австралийской академии гуманитарных наук, Австралийской академии общественных наук, Российской академии наук и Польской академии искусств и наук. Она является лауреатом двух почетных докторских премий - Университета имени Марии Склодовской-Кюри, Польша (2004 г.) и Варшавского университета (2006 г.), а также лауреатом международной премии имени Р.Л. Добрушина (2010) и премии Польского научного фонда (2010).

Анна Вежбицкая - автор более двадцати книг и множества статей, которые, помимо лингвистики, охватывают ряд смежных дисциплин - антропологию, психологию, когнитивистику, философию и религиоведение. В своих междисциплинарных исследованиях она интегрирует язык, культуру и познание, демонстрируя их взаимную обусловленность и конкретные типы их взаимодействия.

Труды Анны Вежбицкой хорошо известны в российском лингвистическом сообществе. Многие ее книги и статьи переведены на русский язык и опубликованы в России, где ее ценят и любят. Среди них - Язык. Культура. Познание (1996), Семантические универсалии и описание языков (1999), Понимание культуры через посредство ключевых слов (2001), Сопоставление культур через посредство лексики и прагматики (2001), Семантические универсалии и базиснье концепть (2011).

Е.В. Падучева в этой связи справедливо отмечает:

Несомненный факт, что влияние работ Вежбицкой на лингвистику в России (речь идет прежде всего об общем языкознании и русистике) заметно больше, чем в какой-либо другой стране. Возможно, здесь сказывается исконная славянская общность, с успехом преодолевающая территориальный и языковой барьер, но скорее всего, дело во внутренней созвучности лингвистических концепций [...]. В русской лингвистике едва ли найдется столь широко и без оглядки цитируемый автор, считая в равной мере как своих (нет пророка в своем отечестве!), так и заграничных (Падучева 2009 [1996]: 629).

В первом томе нашего специального выпуска мы хотим обобщить вклад Анны Вежбицкой в семантику, в разработку теории значения и методологию анализа и описания слов. Большое внимание будет уделено применению раз- 
работанного ею Естественного Семантического Метаязыка (Natural Semantic Metalanguage - NSM). В нашей вводной статье мы коротко остановимся на ее основных идеях.

\section{2. ЕСТЕСТВЕННЫЙ СЕМАНТИЧЕСКИЙ МЕТАЯЗЫК (ЕСМ): КРАТКИЙ ОБЗОР}

Отличительной чертой лингвистических исследований Анны Вежбицкой является ее внимание к смыслу. В то время, когда в лингвистике доминировали формализм и структурализм, Вежбицкая предложила осуществить сдвиг в парадигме лингвистических исследований в сторону семантики, смело заявив, что смысл первичен в языке и анализировать язык следует прежде всего с точки зрения смысла. В одной из своих работ она образно пишет:

Изучать язык, не обращаясь к смыслу, - это все равно, что изучать дорожные знаки с точки зрения их физических свойств (сколько они весят, какой краской покрашены и т.д.), или изучать структуру глаза, игнорируя его способность видеть. (Wierzbicka 1996: 3) (Здесь и далее перевод наш. А.Г., Т.Л.).

Считая смысл важнейшим объектом лингвистического анализа, Вежбицкая предложила гибкий подход к его анализу, который способен обеспечить понимание различных языковых явлений и может быть применен к разным языкам. В книге 1972 года "Semantic Primitives" (Семантические примитивы) она впервые изложила свою теорию, известную теперь под аббревиатурой NSM (Natural Semantic Metalanguage), в русском переводе - ЕСМ (Естественный Семантический Метаязык), которая в настоящее время признана во всем мире одной из ведущих теорий изучения значения.

\section{1. Семантические примитивы}

Вдохновленная идеей философа Готфрида Вильгельма Лейбница о том, что все языки имеют ограниченное число понятий, посредством которых могут быть объяснены другие понятия, Вежбицкая предложила методику выявления этих понятий путем детального лингвистического анализа различных семантических доменов (см. [Wierzbicka 1972]). Лейбниц признавал, что некоторые слова являются более простыми по значению, чем другие, они часто используются и служат вспомогательными для других слов (Leibniz 1987 [1678]: 162). Он называл эти слова «алфавитом человеческих мыслей» (“the alphabet of human thoughts") (см. [Wierzbicka 1972: 6]).

В 2014 году К. Годдард и А. Вежбицкая пишут:

Необходимо попытаться предложить множество определений слов, чтобы выявить, каким словам можно дать определение, а каким нет, и, следовательно, какие слова (или значения слов ) можно рассматривать как элемен- 
тарные строительные блоки, из которых могут быть построены все сложные понятия (и смыслы) (Goddard and Wierzbicka 2014a: 11).

Эту задачу Анна Вежбицкая успешно решает на протяжении всей жизни. Первоначальный список универсальных понятий включал 14 слов (Wierzbicka 1972). Со временем он расширился до 65 и превратился в универсальный метаязык лингвистического анализа. Этому способствовало плодотворное сотрудничество с Клиффом Годдардом (профессором лингвистики в Университете Гриффит в Австралии и одним из авторов этого выпуска), а также с другими коллегами, которые использовали и тестировали метаязык на многих не родственных языках ${ }^{4}$. Метаязык получил название Естественный Семантический Метаязык, поскольку он основан на понятиях, выраженных словами естественного языка (любого естественного языка) и был в основном разработан как инструмент для семантического анализа. Более чем за 40 лет данная теория получила значительное развитие. Она продолжает развиваться и сейчас, некоторые ее аспекты уточняются и конкретизируются (см. [Goddard and Wierzbicka 2002, 2014a, Goddard 2018)].

При определении универсальных понятий теория ЕСМ основывается на гипотезе Лейбница о том, что данные понятия должны одинаково восприниматься людьми независимо от языка, на котором они говорят. Слова, называющие такие понятия, были выделены в результате проб и ошибок и получили название семантических примитивов (semantic primitives/primes). Сюда входят субстантивы (я, ты, что-то), оценочные атрибуты (хоРОший, плохой), ментальные предикаты (ДУМАТЬ, ЗНАТЬ, ХОТЕТЬ), СЛОВа, обоЗНачающИе времЯ (СЕЙЧАС, ДО, ПОСЛЕ), Пространство (ЗДЕСЬ, ДАЛЕКО, БЛИЗКО) и др. (см. Таблица 1). ДЛя того чтобЫ отличить значение семантического примитива от других значений данного слова, их принято обозначать прописными буквами. Данные слова составляют ядро лексики и могут быть использованы для объяснения более сложных смыслов. Помимо слов они могут быть выражены связанными морфемами или фраземами. Они равны лексическим единицам (см. [Apresjan 1992, Mel'čuk 1988]), то есть, если слово является многозначным, значение семантического примитива равно только одному значению этого слова.

Идеи А. Вежбицкой об универсальном метаязыке были успешно апробированы рядом ученых на нескольких типологически различных языках: польском, испанском, малайском, китайском, лао, мангааба-мбула (Goddard \& Wierzbicka 2002), креольском английском (Stanwood 1997), корейском, амхарском, кри (Goddard 2008), французском, итальянском, португальском (Peters 2006), русском (Гладкова 2010), арабском, иврите (Habib 2011) и финском (Vanhatallo et al. 2014). Частичные исследования семантических примитивов ЕСМ были проведены на основе еще двух десятков языков (см. [Goddard and Wierzbicka 1994]).

${ }^{4}$ Важно также отметить сходства и синергию подходов Естественного Семантического Метаязыка, Московской семантической школы (Apresjan 1992, Апресян 2005) и теории «Смысл ↔ Текст» (Mel’čuk 1989, 2012, 2013, 2015). 
Семантические примитивы в английском и русском языках

(по Гладкова 2010, Goddard and Wierzbicka 2014a)

\begin{tabular}{|c|c|}
\hline Я, ТЫ, КТО-ТО, ЧТО-ТО ВЕЩЬ, ЛЮДИ, ТЕЛО & \multirow[t]{2}{*}{ субстантивы } \\
\hline I, YOU, SOMEONE, SOMETHING THING, PEOPLE, BODY & \\
\hline РОД ВИД, ЧАСТЬ & \multirow[t]{2}{*}{ субстантивы отношения } \\
\hline KINDS, PARTS & \\
\hline ЭТОТ, ТОТ ЖЕ, ДРУГОЙ & \multirow[t]{2}{*}{ детерминаторы } \\
\hline THIS, THE SAME, OTHER ELSE & \\
\hline ОДИН, ДВА, НЕКОТОРЫЕ, ВСЕ, МНОГО, МАЛО & \multirow[t]{2}{*}{ квантификаторы } \\
\hline ONE, TWO, SOME, ALL, MUCH MANY, LITTLE FEW & \\
\hline ХОРОШИЙ ХОРОШО, ПЛОХОЙ ПЛОХО & \multirow[t]{2}{*}{ оценка } \\
\hline GOOD, BAD & \\
\hline БОЛЬШОЙ, МАЛЕНЬКИЙ & \multirow[t]{2}{*}{ дескрипторы } \\
\hline BIG, SMALL & \\
\hline ЗНАТЬ, ДУМАТЬ, ХОТЕТЬ, НЕ ХОТЕТЬ, ЧУВСТВОВАТЬ, ВИДЕТЬ, СЛЫШАТЬ & \multirow[t]{2}{*}{ ментальные предикаты } \\
\hline KNOW, THINK, WANT, DON'T WANT, FEEL, SEE, HEAR & \\
\hline ГОВОРИТЬ СКАЗАТЬ, СЛОВА, ПРАВДА & \multirow[t]{2}{*}{ речь } \\
\hline SAY, WORDS, TRUE & \\
\hline ДЕЛАТЬ, ПРОИСХОДИТЬ СЛУЧАТЬСЯ, ДВИГАТЬСЯ & \multirow[t]{2}{*}{ действия, события, движение } \\
\hline DO, HAPPEN, MOVE & \\
\hline БЫТЬ (ГДЕ-ТО), БЫТЬ ЕСТЬ, БЫТЬ (КЕМ-ТО/ЧЕМ-ТО) & \multirow{2}{*}{$\begin{array}{l}\text { расположение, существование, } \\
\text { специффикация }\end{array}$} \\
\hline BE (SOMEWHERE), THERE IS, BE (SOMEONE/SOMETHING) & \\
\hline MOЙ/MOЯ/MOË & \multirow[t]{2}{*}{ принадлежность } \\
\hline (IS) MINE & \\
\hline ЖИТЬ, УМЕРЕТЬ & \multirow[t]{2}{*}{ жизнь и смерть } \\
\hline LIVE, DIE & \\
\hline $\begin{array}{l}\text { КОГДА ВРЕМЯ, СЕЙЧАС, ДО, ПОСЛЕ, ДОЛГО, КОРОТКОЕ ВРЕМЯ, НЕКОТОРОЕ ВРЕМЯ, } \\
\text { МОМЕНТ }\end{array}$ & \multirow[t]{2}{*}{ время } \\
\hline WHEN TIME, NOW, BEFORE, AFTER, A LONG TIME, A SHORT TIME, FOR SOME TIME, MOMENT & \\
\hline ГДЕ МЕСТО, ЗДЕСЬ, НАД, ПОД, ДАЛЕКО, БЛИЗКО, СТОРОНА, ВНУТРИ, КАСАТЬСЯ & \multirow[t]{2}{*}{ пространство } \\
\hline WHERE PLACE, HERE, ABOVE, BELOW, FAR, NEAR, SIDE, INSIDE, TOUCH & \\
\hline НЕ, МОЖЕТ БЫТЬ, МОЧЬ, ПОТОМУ ЧТО, ЕСЛИ & \multirow[t]{2}{*}{ логические концепты } \\
\hline NOT, MAYBE, CAN, BECAUSE, IF & \\
\hline ОЧЕНЬ, БОЛЬШЕ ЕЩЁ & \multirow[t]{2}{*}{ интенсификатор, аугмент } \\
\hline VERY, MORE & \\
\hline КАК TAK & \multirow[t]{2}{*}{ подобие } \\
\hline LIKE $\sim A S$ & \\
\hline
\end{tabular}

Примечания. • Экспоненты примитивов могут быть многозначными, то есть у них могут быть другие дополнительные значения • Экспонентами примитивов могут быть слова, связанные морфемы или фраземы • Они могут быть формально сложными • Они могут иметь лингво-специфичные комбинаторные варианты (аллолексы помечены ) • У каждого примитива есть свои определенные синтактические (комбинаторные) свойства.

\section{2. Универсальная грамматика}

Примитивы образуют (мета)язык, так как обладают способностью сочетаться друг с другом. Как отмечает Вежбицкая, несмотря на очевидные ограничения, метафора Лейбница «алфавит человеческих мыслей» здесь по-прежнему весьма актуальна: концептуальные примитивы - это компоненты, которые необходимо соединить определенным способом, чтобы иметь возможность передать тот или иной смысл (Wierzbicka 1996: 19).

Примитивы объединяются в формулы посредством особого синтаксиса, то есть каждый примитив идентифицируется как способный сочетаться с некоторыми другими примитивами некоторым определенным образом. Они образуют «мини-язык», лежащий в основе каждого языка. Синтаксические свойства примитивов раскрываются в их валентности. Например, примитив СКАЗАТЬ ГОВОРИть 
позволяет использовать универсальную валентность «адресат» и «тема» «кто-то $(\mathrm{X})$ сказал что-то кому-то другому $(\mathrm{Y}) »$, и «кто-то $(\mathrm{X})$ сказал что-то о чем-то (Z)».

Синтаксические свойства примитивов идентифицируются в списках канонических контекстов, или канонических предложений (Goddard and Wierzbicka 1994, 2002), представляющих собой комбинации примитивов, которые отражают их синтаксические свойства и могут быть использованы в толкованиях смыслов. Например, для примитива СКАЗАТь ГОВОРИть определены следующие канонические предложения:

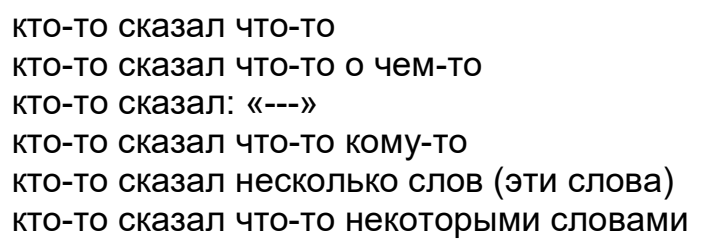

(Goddard and Wierzbicka 2002: 60)

Аналогичным образом канонические предложения формулируются для каждого примитива. Последний обзор канонических предложений представлен в (Goddard and Wierzbicka 2014b).

\section{3. Принцип упрощенных перифраз и семантические толкования}

Примитивы в их канонических комбинациях используются для толкования значений в форме упрощенных перифраз. Семантические толкования на естественном семантическом метаязыке (ЕСM) представляют собой формулы, которые могут быть заменены поясняемыми значениями. Формула такого рода записывается в виде мини-текста, каждый компонент которого начинается с новой строки. Каждый последующий компонент соотносится с предыдущим, а именно имеет анафорическую связь с предыдущими компонентами. Ниже приведен пример семантического толкования английского слова hарpy, сформулированного при помощи ЕCM (Goddard and Wierzbicka 2014a: 103):

\section{He was happy (Он был рад)}

a. this someone thought like this for some time at that time:

b. "many good things are happening to me now as I want

c. I can do many things now as I want

d. this is good"

e. because of this, this someone felt something good at that time

f. like people feel at many times when they think like this for some time

Универсальность понятий и их синтаксических свойств, используемых в ЕСМ, позволяет передавать толкования на любом языке без каких-либо смысловых потерь или добавлений. Русская версия этого толкования будет выглядеть следующим образом:

He was happy (Он был рад)

a. этот кто-то думал так некоторое время в то время:

b. «много хорошего происходит со мной сейчас, как я хочу 


\section{c. я могу делать многое, как я хочу \\ d. это хорошо» \\ е. поэтому этот кто-то чувствует что-то хорошее в это время \\ f. как люди часто чувствуют, когда они думают так некоторое время}

Благодаря универсальности метаязыка это толкование может быть представлено в любой версии ЕСМ точно так же, без какого-либо искажения смысла.

Естественный семантический метаязык является универсальным инструментом, который успешно применяется для анализа различных языковых явлений. Вежбицкая и ее последователи использовали его при изучении эмоций (например, [Wierzbicka 1992, 1999, 2009, 2017]), социальных категорий (Wierzbicka 1997), речевых актов (Wierzbicka 1987), глаголов мышления (Wierzbicka 2006), наименований артефактов и животных ([Wierzbicka 1985]), глаголов движения (Wong, Goddard, Wierzbicka 2016), терминов родства (Wierzbicka 2015) и многого другого. Он также используется при объяснении значений грамматических конструкций (например, [Wierzbicka 1988, 2006, Goddard and Wierzbicka 2016]) .

Идея семантического разложения смыслов Анны Вежбицкой имеет широкую сферу применения как в теории, так и в практике, прежде всего - в обучении иностранным языкам и в практике перевода. Она учит по-новому смотреть на слова и их значения, выявлять в них ранее не замеченные компоненты смыслов и, главное, понимать, что за каждым словом стоит иной мир, который в нем отражается.

Обладая знаниями, полученными при анализе словаря и грамматики, особенно при сопоставлении различных языков, Вежбицкая разработала способ применения своего подхода к изучению воплощенных в языке аспектов культуры. Это привело к идее о существовании ключевых слов культуры (Wierzbicka 1997) и культурных сценариев, а также необходимости их учета в анализе текста. Данные аспекты подхода Вежбицкой будут рассмотрены в следующем номере журнала.

В этот номер, который посвящен главным образом исследованию значения (смысла) на основе ЕСМ, нам прислали статьи друзья, коллеги, ученики и последователи Анны Вежбицкой, которые разделяют и используют ее теоретические положения и подходы к изучению языка в своих исследованиях. Среди них много ярких имен. Кратко представим наших авторов и их работы.

\section{3. КРАТКИЙ ОБЗОР СТАТЕЙ ВЫПУСКА}

Открывает номер И.А. Мельчук (Монреаль, Канада) - известный советский и канадский лингвист, создатель лингвистической теории «Смысл ↔ Текст» и давний друг Анны Вежбицкой. В своей статье он развивает идею семантического разложения смыслов Вежбицкой, которую считает ее основным вкладом в лингвистику. Для иллюстрации важности и плодотворности семантического разложения автор предлагает две мини-модели «Смысл-Текст» - для анг-

5 Полная библиография работ Анны Вежбицкой доступна на ее странице в Интернете на сайте Австралийского национального университета и на странице ECM (NSM Homepage). 
лийского и русского языков, предполагающие четырехуровневый анализ семантический, глубинно-синтаксический, поверхностно-синтаксический и глубинно-морфологический. В статье даются примеры формальных правил, которые соотносят представления соседних уровней.

Клифф Годдард (Брисбен, Австралия), известный австралийский ученый, много лет работающий вместе с Анной Вежбицкой, в своей статье, посвященной анализу семантики этнозоологических категорий, основывается на ее фундаментальных работах (Wierzbicka 1985, 2013) и использует Естественный Семантический Метаязык (ЕСM), в разработке которого он принимал самое непосредственное участие. В статье предлагается семантический анализ слов, принадлежащих к разным уровням английской этнозоологической иерархии, рассматриваются вопросы степени присутствия культурных компонентов в семантике этнозоологических категорий, а также степени различия семантического знания между языковыми сообществами.

Известные канадские ученые Сэлли Райс и Джон Ньюман (Эдмонтон, Канада) с позиций Естественного Семантического Метаязыка исследуют употребление английских базовых глаголов мышления (remember, forget, think, know) и глаголов физического действия (strike, hit, go, run). Данные слова пересекаются с семантическими примитивами Естественного Семантического Метаязыка. В ходе проведенного анализа авторы выявляют новые эпистемические значения и функции этих слов, а также существенные семантические различия, обусловленные их дистирибуцией. В статье продемонстрирована специфичность коллокаций глаголов мышления и глаголов физического действия, а также обсуждается значение лексико-синтаксической идиосинкразии для когнитивной лингвистики.

Джок Онн Вонг (Сингапур) - ученик и последователь Анны Вежбицкой демонстрирует возможность применения Естественного Семантического Метаязыка в процессе преподавания иностранного языка, в данном случае английского. Объектом его исследования являются три логических коннектора - therefore, moreover и in fact, семантику которых важно знать для того, чтобы производить связные тексты и строить логические связи. Автор показывает преимущества использования Естественного Семантического Метаязыка для толкования семантики данных слов перед традиционно используемыми методиками, которые обусловлены тем, что ЕСМ является максимально понятным для учащихся и наименее этноцентричным.

Е.В. Рахилина (Москва, Россия) и А.К. Казкенова (Алматы, Казахстан) анализируют проблему овладения иностранным языком, рассматривая употребление русских существительных единственного и множественного числа казахскими билингвами. В статье находит развитие идея о языковой специфичности правил выбора показателей русского числа, о которой одной из первых писала Анна Вежбицкая, сопоставляя русскую систему с системами других языков - английского и польского (см. [Wierzbicka 1988]). В исследовании показано, что отклонения в числовом поведении имен в текстах билингвов не случайны, а мотивированы, они подчинены определенным семантическим стратегиям, которым следуют 
билингвы, апеллирующие одновременно к двум языковым системам. Авторы отмечают, что нарушения правил использования русского языка билингвами позволяют уточнить эти правила.

Анна А. Зализняк и Е.В. Падучева (Москва, Россия) посвятили свою статью дискурсивным словам, в значение которых входит «мнение говорящего относительно некоторого положения дел». В своих работах Анна Вежбицкая неоднократно обращалась к исследованию форм и способов присутствия говорящего в высказывании (Wierzbicka 1972, 1987, 2003[1991] и др.). Авторы данной статьи предлагают результаты анализа трех русских дискурсивных слов - nожалуй, никак и все-таки, который они проводят на материале Национального корпуса русского языка с применением комплексного подхода, учитывающего опыт экспликации значения языковой единицы разных школ семантического анализа, а также различные методы анализа дискурсивных слов - синхронного, диахронического и контрастивного.

В.Ю. Апресян (Москва, Россия) представляет результаты корпусного исследования русских конструкций с редупликацией цветообозначений. На основе проведенного анализа частотности употребления нередуплицированных цветообозначений и их коллокационных свойств установлена иерархия базовых для русского языка цветов, которая отражает как межъязыковые «универсалии визуальной семантики» Анны Вежбицкой, так и лингвоспецифические характеристики. Автор показывает важность корпусного анализа при изучении терминов цветообозначения и конструкций с редупликацией цветообозначений и учет как семантических, так и прагматических факторов при их интерпретации.

В статье А.Д. Шмелева (Москва, Россия) развивается и уточняется семантический анализ русских слов свобода и воля и их производных (свободнылй, вольный, вольность и т.д.), предложенный в работах Анны Вежбицкой (Wierzbicka 1997: 138-148, 154-155), а также в ранее опубликованных работах автора (Шмелев $2003,2013)$. Данные слова анализируются как в синхронном, так и в диахроническом аспекте. Особое внимание уделяется проблеме их перевода. В статье показано, что переводные эквиваленты лингвистической единицы могут рассматриваться как ценный источник сведений о ее семантике, что особенно эффективно, когда речь идет о лингвоспецифичных словах.

Выпуск завершается обзорной статьей Е.Г. Которовой (Зелёна-Гура, Польша), в которой рассматриваются три работы Анны Вежбицкой, посвященные анализу терминов родства. В статье показывается, как Вежбицкая использует новый способ анализа терминов родства с помощью методологии Естественного Семантического Метаязыка. Данный подход позволяет успешно преодолевать проблему евроцентризма в анализе терминологии родства в различных языках с помощью универсалий человеческого мышления.

\section{4. ЗАКЛЮЧЕНИЕ}

На этом наш выпуск, посвященный вкладу Анны Вежбицкой в лингвистику, не заканчивается. Он будет продолжен в следующем номере, где речь пойдет о взаимодействии языка и культуры, проявляющемся в семантике, прагматике, дискурсе и других областях. 
Мы благодарим всех авторов этого номера за участие в нашем проекте и вместе с ними, а также со всеми читателями нашего журнала еще раз сердечно поздравляем Анну Вежбицкую с замечательным юбилеем!

Низкий Вам поклон и благодарность, дорогая Анна, за Ваши труды и идеи, которыми Вы всегда щедро делитесь, за вдохновение, постоянную поддержку и бесконечную доброту.

\section{ACKNOWLEDGEMENTS}

We would like to thank the authors of this issue for their contributions and participation in the reviewing process. We also thank external reviewers. We are grateful to Igor Mel'čuk for his valuable comments to this article and active participation in the preparation of this issue. All errors remain ours.

\section{БЛАГОДАРНОСТИ}

Мы благодарим авторов этого номера за их статьи и участие в процессе рецензирования. Мы также благодарим всех рецензентов. Особое спасибо выражаем Игорю Александровичу Мельчуку за его ценные комментарии к этой статье и активное участие в подготовке номера.

(C) Anna Gladkova, Tatiana Larina, 2018 А.Н. Гладкова, Т.В. Ларина, 2018

\section{REFERENCES / СПИСОК ЛИТЕРАТУРЫ}

Apresjan, Juri (1992). Lexical Semantics: User's guide to contemporary Russian vocabulary. [Translation of Apresjan, J. 1974. Leksičeskaja semantika: sinonimičeskie sredstva jazyka. (In Russ.)] Ann Arbor: Karoma Publishers, Inc.

Goddard, Cliff (2011). Semantic analysis: A practical introduction. $2^{\text {nd }}$ ed. Oxford: Oxford University Press.

Goddard, Cliff (2016). Semantic molecules and their role in NSM lexical definitions. Cahiers de Lexicologie, 2 (109), 13-34.

Goddard, Cliff (2018). Ten Lectures on Natural Semantic Metalanguage: Exploring language, thought and culture using simple, translatable words. Leiden: Brill.

Goddard, Cliff (Ed.) (2008). Cross-linguistic Semantics. Amsterdam: John Benjamins.

Goddard, Cliff (2018). Minimal English for a Global World: Improved Communication Using Fewer Words. London: Palgrave Macmillan.

Goddard, Cliff, and Anna Wierzbicka (2002). Semantic Primes and Universal Grammar. In Goddard, C., and A. Wierzbicka (eds). Meaning and Universal Grammar: Theory and empirical findings. Vol. I. Amsterdam: John Benjamins. 41-85.

Goddard, Cliff, and Anna Wierzbicka (2014a). Words and Meanings: Lexical Semantics Across Domains, Languages, and Cultures. Oxford: Oxford University Press.

Goddard, Cliff, and Anna Wierzbicka (2014b). Semantic fieldwork and lexical universals. Studies in Language. 38 (1), 80-127.

Goddard, Cliff, and Anna Wierzbicka (2016). It's mine! Re-thinking the conceptual semantics of possession through NSM. Language Sciences, 56, 93-104.

Goddard, Cliff, Wierzbicka, Anna and Wong, Jock (2016). "Walking" and "running" in English and German: The cross-linguistic semantics of human locomotion. Review of Cognitive Linguistics. 14(2):303 - 336. DOI: 10.1075/rcl.14.2.03god. 
Goddard, Cliff, and Anna Wierzbicka (Eds.) (1994). Semantic and lexical universals: Theory and empirical findings. Amsterdam: John Benjamins.

Goddard, Cliff, and Anna Wierzbicka (Eds.) (2002). Meaning and Universal Grammar: Theory and empirical findings. Vols. I, II. Amsterdam: John Benjamins.

Habib, Sandy (2011). Contrastive lexical-conceptual analysis of folk religious concepts in English, Arabic and Hebrew. PhD Thesis. Armidale, Australia: University of New England.

Leibniz, Gottfried Wilhelm (1956). Preface to an Edition of Nizolius. In Leibniz, G.W. Philosophical Papers and Letters: A selection. Translated and edited, with Introduction by Loemker, L.E. Vol. 1. Chicago: The University of Chicago Press. 186-202.

Leibniz, Gottfried Wilhelm. (1987[1678]). The Analysis of languages. In Dascal, M. Leibniz, language, signs and thought: A collection of essays. Amsterdam: John Benjamins. 161-165.

Mel'čuk, Igor (1988). Semantic description of lexical units in an explanatory combinatorial dictionary: Basic principles and heuristic criteria. International Journal of Lexicography, 1, 165-188.

Mel'čuk, Igor (1989). Semantic primitives from the viewpoint of of the Meaning-Text linguistic theory. Quaderni di Semantica 10, 65-102.

Mel'čuk, Igor (2012). Semantics: From Meaning to Text. Vol. 1. Amsterdam/Philadelphia: John Benjamins.

Mel'čuk, Igor (2013). Semantics: From Meaning to Text. Vol. 2. Amsterdam/Philadelphia: John Benjamins.

Mel'čuk, Igor (2015). Semantics: From Meaning to Text. Vol. 3. Amsterdam/Philadelphia: John Benjamins.

Mel'čuk, Igor (2016). Language: From Meaning to Text. Moscow / Boston: Academic Studies Press.

Peeters, Bert (Ed.) (2006). Semantic Primes and Universal Grammar: Empirical evidence from the Romance languages. Amsterdam: John Benjamins.

Stanwood, Ryo. (1997). The primitive syntax of mental predicates in Hawai'i Creole English: A textbased study. Language Sciences 19 (3): 209-217.

The Natural Semantic Metalanguage Homepage https://intranet.secure.griffith.edu.au/schoolsdepartments/natural-semantic-metalanguage.

Wierzbicka, Anna (1972). Semantic Primitives. (Translated by Wierzbicka, A., and J. Besemeres) Frankfurt: Athenäum Verlag.

Wierzbicka, Anna (1985). Lexicography and Conceptual Analysis. Ann Arbor: Karoma.

Wierzbicka, Anna (1987). English speech act verbs: A semantic dictionary. Sydney: Academic Press.

Wierzbicka, Anna (1988). The Semantics of Grammar. Amsterdam: John Benjamins.

Wierzbicka, Anna (1990). The meaning of colour terms: Semantics, culture, and cognition. Cognitive Linguistics, 1(1), 99-150.

Wierzbicka, Anna (1992). Semantics, culture, and cognition: Universal human concepts in culturespecific configurations. Oxford: Oxford University Press.

Wierzbicka, Anna (1996a). Semantics: Primes and universals. Oxford: Oxford University Press.

Wierzbicka, Anna (1997). Understanding cultures through their key words: English, Russian, Polish, German, and Japanese. Oxford: Oxford University Press.

Wierzbicka, Anna (1999a). Emotions across languages and cultures: Diversity and universals. Cambridge: Cambridge University Press.

Wierzbicka, Anna (2002). Russian cultural scripts: The theory of cultural scripts and its applications. Ethos 30 (4): 401-432. 
Wierzbicka, Anna (2003/1991). Cross-Cultural Pragmatics. $2^{\text {nd }}$ ed. Berlin: Mouton de Gruyter.

Wierzbicka, Anna (2005). There Are No "Colour Universals" but There Are Universals of Visual Semantics. Anthropological Linguistics, Vol. 47, No. 2 (Summer, 2005), 217-244.

Wierzbicka, Anna (2006). English: Meaning and Culture. Oxford: Oxford University Press.

Wierzbicka, Anna (2013). Polish zwierzęta 'animals' and jabtka 'apples': an ethnosemantic inquiry. In Głaz, A., Danaher, D.S. \& Łozowski, P. (eds.), The linguistic worldview: Ethnolinguistics, cognition, and culture. London: Versita, 137-159.

Wierzbicka, Anna (2009). Language and metalanguage: Key issues in emotion research. Emotion Review 1(1), 3-14.

Wierzbicka, Anna (2014). Imprisoned in English: The hazards of English as a default language. New York: Oxford University Press.

Wierzbicka, Anna (2015). New perspectives on kinship: Overcoming the Eurocentrism and scientism of kinship studies through lexical universals. In Nancy Bonvillain (ed.), The Routledge handbook of linguistic anthropology. New York: Routledge. 62-79.

Vanhatalo, Ulla, Heli Tissari, and Anna Idström (2014). Revisiting the universality of Natural Semantic Metalanguage: a view through Finnish. SKY Journal of linguistics 27, 67-94.

Апресян Ю.Д. О московской семантической школе. Вопросы языкознания, 1, 3-30, 2005. [Apresjan, J.D. 2005. O moskovskoi semanticheskoi shkole (About the Moscow School of Semantics). Voprosy yazykoznaniya, 1, 3-30.]

Вежбицкая А. Язык. Культура. Познание. М., 1997. [Wierzbicka, Anna (1996b). Language. Culture. Cognition. Moscow. (In Russ.)]

Вежбицкая А. Семантические универсалии и описание языков / Пер. с англ. А.Д. Шмелева; под ред. Т.В. Булыгиной. М.: Языки русской культуры, 1999. [Wierzbicka, Anna (1999b). Semantic universals and description of languages. Translated from English by A. Shmelev. Moscow, Yazyki russskoi kul'tury. (In Russ.)]

Вежбицкая А. Понимание культуры через посредство ключевых слов / Пер. с англ. А.Д. Шмелева. М.: Языки славянской культуры, 2001a. [Wierzbicka, Anna (2001a). Understanding culture through keywords. Translated from English by A. Shmelev. Moscow: Yazyki slavyanskoi kul'tury. (In Russ.)]

Вежбицкая А. Сопоставление культур через посредство лексики и прагматики. М.: Языки славянской культуры, 2001б. [Wierzbicka, Anna (2001 b). Comparison of cultures through vocabulary and pragmatics. Moscow: Yazyki slavyanskoi kul'tury. (In Russ.)]

Вежбицкая А. Семантические универсалии и базисные концепты. М.: Языки славянских культур, 2011. [Wierzbicka, Anna (2011). Semantic universals and basic concepts. Yazyki slavyanskikh kul'tur. (In Russ.)]

Гладкова А.Н. Русская культурная семантика: Эмоции, ценности, жизненные установки. М.: Языки славянских культур. 2010. [Gladkova, Anna (2010). Russian cultural semantics: Emotions, values, attitudes. Moscow: Yazyki slavyanskoi kul'tury. (In Russ.)]

Падучева Е.В. Феномен Анны Вежбицкой // Cmaтьи разных лет. М.: Языки славянских культур. (Предисловие к книге Анны Вежбицкой «Язык, культура, познание» М.: Русские словари, 1996). 2009. [Paducheva E.V. (2009). The phenomenon of Anna Wierzbicka. In: Stat'i raznykh let. Moscow: Yazyki slavyanskoi kul'tury. (In Russ.)]

Шмелев А.Д. В поисках мира и лада // Логический анализ языка. Космос и хаос: концептуальные поля порядка и беспорядка. М.: Индрик, 2003. C. 54-72. [Shmelev, A.D. (2003). In search of peace and harmony. In: Arutyunova, N.D. (ed.) Logical analysis of language: conceptual fields of order and disorder. Moscow: Indrik, 54-72. (In Russ.)] 
Шмелев А.Д. Историческая память слова в прозе Александра Солженицына: мир и воля // Солженицынские тетради. Вып. 2. М.: Русский путь, 2013. С. 115-135. [Shmelev, A.D. (2013). The historical memory of words in the prose of Aleksandr Solzhenitsyn: The Russian words mir and volia. Studying Solzhenitsyn. Issue 2. Moscow: Russkii put', 115-135. (In Russ.)]

\section{For citation:}

Gladkova, Anna and Larina, Tatiana (2018). Anna Wierzbicka, Words and The World. Russian Journal of Linguistics, 22 (3), 499—520. doi: 10.22363/2312-9182-2018-22-3-499-520.

\section{Для цитирования:}

Gladkova A., Larina T. Anna Wierzbicka, Words and The World // Вестник Российского университета дружбы народов. Серия: Лингвистика = Russian Journal of Linguistics. 2018. Т. 22. № 3. C. 499-520. doi: 10.22363/2312-9182-2018-22-3-499-520.

\section{Bionotes:}

ANNA GLADKOVA is a Lecturer in English as an International Language at Monash University and an Honorary Lecturer in Linguistics at the Australian National University. She received her PhD in Linguistics from the Australian National University. Her research interests include semantics, pragmatics, language and culture interface, cognitive linguistics and Natural Semantic Metalanguage. She has taught linguistics and applied linguistics at the Australian National University and University of New England (Australia) as well as University of Sussex and University of Brighton (United Kingdom). She is member of the Editorial Board of Corpus Pragmatics and Yearbook of Corpus Linguistics and Pragmatics (Springer).

Contact information: angladkova@gmail.com

TATIANA V. LARINA is Full Professor at RUDN University, and is the Editor-in-Chief of the Russian Journal of Linguistics. Her research interests embrace language, culture and communication; intercultural pragmatics, intercultural communication, communicative ethnostyles, and (im)politeness theory. Key publications: Kategoriya vezhlivosti i stil' kommunikatsii: sopostavlenie angliiskikh i russkikh lingvokul'turnykh traditsii [Politeness and Communicative Styles: comparative analyses of English and Russian communicative traditions], Moscow, 2009; Anglichane i russkie: Yazyk, kul'tura, kommunikatsiya [The English and the Russians: Language, Culture and Communication], Moscow, 2013; Osnovy mezhkul'turnoi kommunikatsii [Intercultural Communication], Moscow, 2017; Culture-Specific Communicative Styles as a Framework for Interpreting Linguistic and Cultural Idiosyncrasies // International Review of Pragmatics, 7 (3), 195-215, 2015.

Contact information: tatiana_tv@rudn.ru

\section{Сведения об авторах:}

АННА ГЛАДКОВА получила докторскую степень по лингвистике в Австралийском национальном университете. Она преподает в Университете Монаш (Австралия), а также является почетным преподавателем лингвистики в Австралийском национальном университете. Ее научные интересы включают семантику, прагматику, взаимодействие языка и культуры, когнитивную лингвистику и Естественный Семантический Метаязык. Она преподавала лингвистику и прикладную лингвистику в Австралийском национальном университете и Университете Новой Англии (Австралия), а также в Университете Сассекса и Университете Брайтона (Великобритания). Она является членом редколлегии журнала Корпусная Прагматика и Ежегодника по корпусной лингвистике и прагматике (издательство Springer).

Контактная информация: angladkova@gmail.com 
ЛАРИНА ТАТЬЯНА ВИКТОРОВНА - доктор филологических наук, профессор кафедры иностранных языков филологического факультета Российского университета дружбы народов, главный редактор журнала Вестник Российского университета дружбы народов. Серия: Лингвистика / Russian Journal of Linguistics. Сфера научных интересов: язык, культура, коммуникация; межкультурная прагматика; межкультурная коммуникация; этнокультурные стили коммуникации; теория (не)вежливости. Основные публикации: Категория вежливости и стиль коммуникации: Сопоставление английских и русских лингвокультурных традиций. М.: Языки славянских культур, 2009; Англичане и русские: Язык, культура, коммуникация. М.: Языки славянских культур, 2013; Основы межкультурной коммуникации. М.: Академия, 2017; Culture-Specific Communicative Styles as a Framework for Interpreting Linguistic and Cultural Idiosyncrasies // International Review of Pragmatics, 7 (3), 195-215, 2015.

Контактная информация: larina_tv@rudn.ru 